\title{
Training of Gluten and Casein Free Snack Processing for Mothers of Children with Autism Spectrum Disorder
}

\author{
Novriani Tarigan",Ginta Siahaan, Dini Lestrina \\ Department of Nutrition, Politeknik Kesehatan, Medan, Indonesia
}

\begin{abstract}
The gluten and casein-free (GCF) diet is one alternative ways in handling children with autism spectrum disorders (ASD). The aim of this community service activities was to improve the attitudes, motivations and skills of the mothers in order to be able to prepare GCF diet that are safe for consumption by ASD children. The target participants of this community service activity were 25 mothers of ASD children from the Pondok Peduli Autis Foundation in Medan. Stages of implementation consisted of socializing the activities, pre-test, and counseling on a GFC diet, training and demonstrations on processing of GCF snacks, as well as evaluating activities in the form of a post-test. The GCF products made in the training activities were purple sweet potato pudding, pumpkin pudding, hunkwe pudding, corn bakwan, cassava omelette, cassava pastel, and cassava croquette with vegetables. The average pre-test results on the participants' knowledge about GCF diets was 45.6. After counseling twice by using a "Booklet" tools and training on the processing of GCF products, there was an increase in knowledge to 81.9. Furthermore, after regularly consuming the GCF foods prepared based on this program, more than $50 \%$ participants found their autis children improvement in learning concentration and no longer hyperactive.
\end{abstract}

Keywords: Gluten and casein free diet, Autism spectrum disorder, Corn bakwan

Abstrak. Diet bebas gluten dan kasein merupakan salah satu alternative dalam penanganan anak-anak yang mengalami gangguan spectrum autisme (Autism Spectrum Disoder). Kegiatan pengabdian masyarakat bertujuan untuk meningkatkan sikap, motivasi dan keterampilan ibu-ibu untuk mampu menyediakan makanan selingan bebas gluten dan bebas kasein sehingga aman dikonsumsi oleh anak-anak penderita autis. Sasaran peserta dari kegiatan pengabdian pada masyarakat ini adalah 25 orang ibu-ibu dari peserta didik di Yayasan Pondok Peduli Autis Medan.

Tahapan pelaksanaan terdiri dari sosisalisasi kegiatan, pre test, serta penyuluhan *Corresponding author at: Politeknik Kesehatan, Medan, Indonesia

E-mail address: tarigannovriani@gmail.com

Copyright ( 2018 Published by Talenta Publisher, ISSN: 2621-4830

Journal Homepage: https://talenta.usu.ac.id/jst 


\begin{abstract}
mengenai diet bebas gluten dan kasein, pelatihan dan demo mengolah snack bebas gluten dan kasein, serta evaluasi kegiatan dalam bentuk post test. Produk pangan bebas gluten dan kasein yang dibuat adalah pudding ubi jalar ungu, pudding hunkwe, pudding labu kuning, bakwan jagung, dadar singkong, pastel singkong, dan kroket singkong isi sayuran. Hasil pre test pengetahuan peserta mengenai diet bebas gluten dan kasein menunjukkan nilai rata-rata peserta adalah 45,6, dari nilai maksimum sebesar 100. Setelah dilakukan dua kali penyuluhan dengan alat bantu "Booklet" dan pelatihan demo pengolahan produk bebas gluten dan kasein, terjadi peningkatan pengetahuan menjadi 81,9. Berdasarkan hasil wawancara terhadap peserta pada saat evaluasi akhir diketahui bahwa terdapat perubahan pada perilaku anak penderita autis seperti meningkatnya konsentrasi belajar anak (terdapat pada 50\% anak) dan tidak lagi hiperaktif.
\end{abstract}

Kata Kunci: Diet bebas gluten dan kasein, gangguan spectrum autisme, bakwan jagung

Received 25 February 2020 | Revised 27 March 2020| Accepted 7 April 2020

\title{
1. Introduction
}

Autism Spectrum Disorder (ASD) is a pervasive developmental disorder that is generally seen in the first three years [1]. Yuwono [2] also mentioned that ASD is very complex neurobiological development disorders, including attention deficit disorder with hyperactivity or attention deficit hyperactivity disorder, behavioral disorders, infantile autism, social interaction and communication, and language delays caused by dysfunction of the dipeptidyl-peptidase IV (DPP-IV) enzyme. The absence or decrease of DPP-IV, causing casein and gluten intake cannot be digested, increasing morphine effect symptoms: tantrums, screaming, crying, hitting, and other hyperactivity [3]. Most of the studies confirmed that toxic heavy metals such as mercury, aluminium, and lead associated with ASD development. There are significantly higher levels of toxic heavy metals in the hair samples of ASD children. It is due to exposure to toxic metals through drinking water, foods, or drugs like a vaccine. The possible explanation for this is that autistic children might lack of the ability to detoxify toxins, resulting in an accumulation of toxic substances in the body, leading to an alteration in the biochemical process taking place in the body [4].

Based on data from the World Health Organization (WHO), the prevalence of ASD has increased from 4-6 per 10,000 births in 1900's to 60 per 10,000 birth in 2000's or ratio 1:250 children [5]. The survey results on 2012 by Autism Concerned Community Forum stated that the number of autistic people in North Sumatra is around 10,000 
people [6]. There are at least 13 special schools for children with autism in the Medan city, with an average number of 15-35 students who have different symptoms of autism. There are some alternative treatments to reduce the risk of ASD, including the adoption of elimination diets, in particular, the gluten and casein-free (GCF) diets [7], minimizing the consumption of food contaminated by heavy metals or preservation agents such as canned food. On the other hand, the children generally like tasty and sweet food as well as junk food such as burgers, grilled meatballs, and attractive colored drinks, which are allegedly vulnerable to contamination of synthetic dyes and heavy metals [8].

The elimination of gluten implies the exclusion of all food items containing wheat, barley, oats, and rye such as flours, bread, cookies, noodle and pasta, and other bakery products made from these cereals. The elimination of casein means that no intake of dairy products including milk, yogurt, cheese, butter, ice cream, and among others [9]. Moreover, the adoption of elimination diets should be adjusted to local conditions. In Indonesia, food products that must be avoided for children with ASD are snack products that use flour and casein because rice as the staple does not contain gluten. Snack products containing carbohydrate, fat, and protein contribute around $25 \%$ of the Recommended Daily Allowance (RDA) to energy. Therefore, giving snacks to children with ASD can help meet their daily energy needs. The success of providing snacks should be accompanied by health promotion by providing nutrition education to mothers who have children with ASD. Nutrition education is meant to be in the form of persuasion, appeals, invitations to provide information, awareness, and training [10].

Siahaan [11] research found that providing GCF snacks combined with education on nutrition to autistic children can reduce metal levels in their hair from $31.45 \mathrm{ppm}$ to $17.9 \mathrm{ppm}$ compared to the group who were only given GCF snacks without nutrition education (22.85 ppm). This situation helps improve clinical manifestations because the autistic person does not experience tantrums and decreases from pervasive developmental disorders. This community service activity aimed to increase the knowledge about food management, attitudes, and motivations of the mothers who have autistic children. 


\section{Methods}

The target audience in this community service activity was mothers who have autistic children in Pondok Peduli Autis Foundation, on Jalan Bhayangkara Medan. There are 35 students who come from various locations in Medan. However, for this community service activity, only 25 mothers were willing to attend.

This community service was conducted for 2 months with several steps of activities:

1. Socialization and requests for willingness to participate in community service activities.

2. Pre-test activities to find out the initial knowledge of the target audience about food management in children with autism.

3. Extension about the benefits of local foods that have high antioxidants and ASD using the Booklet tool.

4. Training and demonstration on the processing of various GCF snacks were carried out twice.

5. Post-test activities to determine the final knowledge of the target audience about the use and processing of local food which is safe and suitable for children with autism.

Evaluation of the results from the implementation of community service by the target audience through filling out the questionnaire and interviews.

\section{Results and Discussions}

\subsection{Socialization activity}

The socialization activity was carried out by conveying the previous research results regarding the provision of GCF foods for autistic children. The results of this study indicated that the behavior of students with autism who are given GCF food changed compared to the children without consuming GCF food. Therefore, it is necessary to further conduct GCF food processing training activities, so parents, especially mothers of children with autism, can apply it to their children. From the results of this socialization, there are 25 mothers with autistic children who are willing to attend training, with characteristics as in Table 1. 
Table 1. Characteristics of mothers of autistic children as participants in the community service activity

\begin{tabular}{lrr}
\hline \multicolumn{1}{c}{ Characteristics } & $\mathrm{n}$ & $\%$ \\
\hline Mothers Age Group (years) & & \\
$<20$ & 1 & 4 \\
$20-29$ & 3 & 60 \\
$30-39$ & 15 & 24 \\
$40-49$ & 6 & \\
\hline Mother's Education: & 1 & 4 \\
$\quad$ Primary School & 1 & 4 \\
Junior High Schoold & 8 & 32 \\
Senior High School & 15 & 60 \\
University & & \\
Mothers Job: & 16 & 64 \\
Housewife & 4 & 16 \\
Enterpreneur & 3 & 12 \\
Trader & 2 & 8 \\
Employer & 25 & 100 \\
\hline
\end{tabular}

Table 1 shows that the majority of mothers aged between 30-39 years (60\%), with university education level (60\%) and housewives (64\%).These characteristics greatly support the success of the training activities that will be carried out. In the training activities, a booklet containing the results of Ginta's research [11] and theoretical review was prepared. The booklets were used as a tool to make it easy for mothers to understand the material provided. Besides, information on ASD, food ingredients that do not contain gluten, healthy food ingredients for autistic children, a gluten and casein free diet, recipes and photos of GCF snacks were included in the booklets.

\subsection{Extension about authistic children}

The purpose of this extension activity was to increase participants' understanding of children's autism. Counseling was done in the classroom when students' class time is over, where mothers were usually come to pick up their children after school. The schedule and venue were chosen carefully so that all participants can participate in the extension activities. A pretest was conducted at the beginning of the activity, in which the participants were asked to fill in a questionnaire containing questions about the mothers' knowledge about autism. After that, materials about autism in children, the role of food in preventing or decreasing clinical manifestations of children suffering from autism such as tantrums and hyperactivity were given to the mothers.

Based on the results of the pretest, participants' knowledge about autism symptoms and foods containing gluten and casein was low (the average correct answer was only 
45.6\%). During the counseling session, the participants were very enthusiastic to follow the activities. They also asked many questions about good food for autistic children. Fatmalasari [12] introduces qualitative research methods with in-depth interviews that can analyse the mothers' understanding of the GCF diet. The results indicated that after the mothers' knowledge about GCF diet increased after the counseling. However, they have no concept of the GCF diet implementation to their children. Therefore, the training on GCF processing must be continued, so that the mothers can apply the benefit to their autistic children.

\subsection{Training of gluten and casein free snacks processing}

Training was carried out by cooking demonstrations of GCF snacks at the training location. Based on the results of a brief interview with mothers with autistic children, information was obtained that there was a tendency for children with autism to prefer fried foods. Therefore, in this activity training was given on making corn bakwan, cassava pastel and cassava croquette filled with vegetables which are fried snacks. Furthermore, the participants were also trained for un-fried food processing, such as pumpkin pudding, purple sweet potato pudding, hunkwe pudding and cassava omelete, as shown in Figure 1. During the training activities, the participants of the training followed enthusiastically.

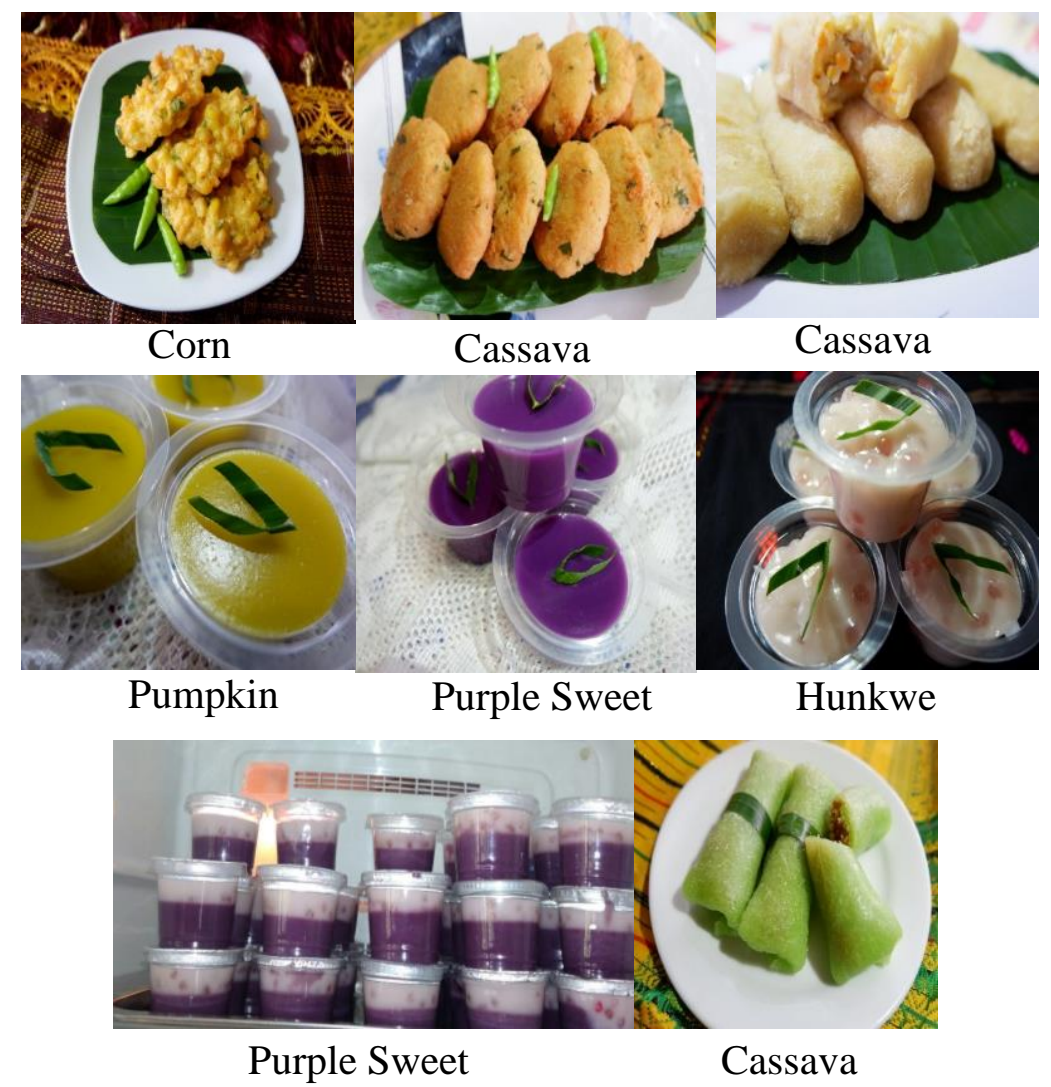

Figure 5. Gluten and casein free snack products 


\subsection{Activity evaluations}

Pre and post-tests are usually used to measure the knowledge gained of participants during the training activity [13]. A baseline assessment was administered before the extension and training activity and a follow-up assessment and evaluation were run after the training activity. Evaluation results indicate that an increase in the level of participants' knowledge namely mothers of autistic children about providing safe food for their children. Based on the interview results it is known that as many as $50 \%$ of children who are given non-gluten snacks increase their concentration of learning. The results of the interview also showed that the type of snack that is preferred by autistic children is corn bakwan.

\section{Conclusions}

Counseling and training activities on gluten and casein-free diets for mothers who have autistic children can improve mothers' understanding of a good diet for autistic children. After counseling and training on the benefits of the gluten and casein-free diet, mothers of autistic children become more motivated to process and provide their snacks for their children. Evaluation results show that mothers experience increased skills in varying good snacks in their autistic children.

\section{References}

[1] B. Wright, and C. Williams, Intervention and support for parents of children and young people on the autism spectrum. A resource for trainers. London: Jessica Kingsley Publishers. 2007.

[2] J. Yuwono, Memahami anak Autistik (Kajian Teoritik Dan empirik). [Understanding Autistic children (Theoretical and Empirical Studies)]. Bandung: Alfabeta. 2009.

[3] Nugraheni and S. Achadi, Diet \& Autisme. [Diet and Autism]. Pustaka, Semarang. 2009.

[4] M. A. Gaza, L. Hakim, A. Sabarudin, and S. B. Sumitro, "Evaluation on mercury, cadmium, and lead in the hair sample as an indicator of autism for children". International Journal of Pharmaceutical and Clinical Research, vol. 9, no. 12, pp. 710-715, 2017.

[5] R. Sutardi, Jangan Bingung Dengan Istilah Autisme, Autistik, PDD, PDD-NOS, dlsb. [Don't Be Confused by Autism, Autistic, PDD, PDD-NOS, etc.]. http://kesehatan.kompasiana.com/ibudananak/2011/08/13/jangan-bingung-dengan -istilah-autisme-autistik-pdd-pdd-nos-dlsb/. (2011) [Accessed on 26 Januari 2017].

[6] Octiara, Essie and Z. Fahnia, "Percentage of Malocclusion in Autis and Normal Children in Medan”. Dentika Dental Journal, vol. 18, no. 2, pp. 141-146, 2014.

[7] M. Alpert, “The autism diets”. Science American. vol. 296, pp. 19-20, 2007. 
[8] F. G. Winarno, Ilmu Bahan Makanan. [Food Ingredient Science]. Gramedia: Jakarta. 2008.

[9] S. Notoadmodjo, Promosi Kesehatan dan Perilaku Kesehatan. [Health Promotion and Health Behavior]. Rineka Cipta: Jakarta. 2012.

[10] S. Mari-Bauset, I. Zazpe, A. Mari-Sanchis, A. Liopis-Gonzalez, and M. Morales-Suarez-Varela, "Evidence of the gluten-free and casein free diet in autism spectrum disorders: A systematic review". Journal of Child Neurology, vol. 29, no. 12, pp. 1718-1727, 2014.

[11] G. Siahaan, D. Lestrina, and N. Tarigan, Profil Logam Pro-Oksidan $(\mathrm{Pb})$ dan Antioksidan ( $\mathrm{Zn})$ serta Dampak Pemberian Snack Free Gluten Casein dan Pendidikan Gizi Terhadap Manifestasi Klinik Anak Autisme di Medan. Laporan Penelitian Hibah Bersaing. [Metal Profile of Pro-Oxidant $(\mathrm{Pb})$ and Antioxidant (Zn) and the Impact of Casein and Gluten Free Snack and Nutrition Education on Clinical Manifestations of Children with Autism in Medan. "HibahBersaing" Research Report]. Politeknik Kesehatan Medan. 2017.

[12] Y. Fatmalasari, W. Hery, and U. P. Dyah, "Pemahaman Mengenai Diet Gluten Free Casein Free (GFCF) serta Penerapannya Pada Anak Autis Tingkat Sekolah Dasar SLB C Yakut Purwokerto". [Understanding of the Gluten Free Casein Free (GFCF) Diet and Its Application in Autistic Children in Elementary School SLB C Yakut Purwokerto]. J.Gipas, vol. 1, no. 1, 2017.

[13] T. Shivaraju, G. Manu, M. Vinaya, and M. K. Savkar, "Evaluating the effectiveness of pre- and post-test model of learning in a medical school Padmanabha". National Journal of Physiology, Pharmacy and Pharmacology, vol. 7, no. 9, pp. 947-951, 2017. 